\title{
A hydrogenic electrolyzer for fuels
}

\author{
Bogdan Żółtowski, Prof., \\ Mariusz Żółtowski, Ph.D. \\ University of Technology and Life \\ Science in Bydgoszcz, Poland
}

\begin{abstract}
In this work - in view of still decreasing crude oil resources and increasing fuel prices - are presented issues concerning research on development of other, alternative fuel sources including those used in water, land and air transport means. One of them is hydrogen which,while burning, does not produce noxious carbon dioxide but only side effects such as heat and clean water.

It is almost true that along with sudden drop of availability and rising price of crude oil many countries face economical paralysis. Any of alternative sources is not capable of supplying even only a basic amount of such energy, not mentioning the whole amount of energy demanded by our civilization. Hydrogen as an independent fuel for internal combustion engines has yet to go a long way to commercialization. to be Co-burning systems (combustion of mixtures )of today used hydrocarbon fuels combined with hydrogen seem closer to this aim. As proved in many investigations the substitution of a part of hydrocarbon fuel by hydrogen enables to make use of beneficial features of both the fuels.

One of possible solutions of the problem may be application of an innovative hydrogenic fuel electrolyzer which is presented and evaluated in this paper.
\end{abstract}

Keywords: substitute fuel, hydrogen, biofuels, electrolysis, co-burning the fuels

\section{Introduction}

In strategic plans it has been assumed that till 2020 alternative fuels would replace at least $20 \%$ of fuels used for transport aims. Political strategy assumes that even partial freeing from dependence on crude oil is rational and necessary. Among alternative fuels, propane-butane gas has found so far wide application in practice, and, natural gas and hydrogen is lately preferred. This is hydrogen which, despite technical difficulties associated with its use, may become a fuel of the nearest future. If oil prices increase, alternative energy sources will become profitable, and as a result a smooth transition to the alternatives will be possible $[1,2,4]$. Worth mentioning, that from the economic point of view we never will face a problem of depletion of raw materials because price impulse will ever help to find an appropriate alternative $[1,3,5,8,14,20]$.

Along with sudden drop of crude oil availability and rise of its price, it is almost certain that :

- agricultural industry which is deeply dependent on the fuel and its products, will not be capable of producing as much food as to-day,

- certain enterprises will become bankrupts;

- confusion will overcome worldwide financial markets;

- many people will be deprived from heating their houses at all or forced to reduce it;

- dynamically increasing costs of transport will disturb free flow of goods, including various materials and food products $[2,3,6,13,15,19]$.

Potential of hydrogen is so immense that it is often called the fuel of 21st century and its price will sometime become more competitive in comparison with other energy sources than it is to day. Hydrogen resources are practically unlimited as it is a renewable fuel and water is the only waste product from its combustion. Hydrogen cannot be practically found in the form of a free gas, but in the form of chemical compounds. There is a difficulty in hydrogen gaining because it appears in the form of compounds such as water, hydrocarbons, hydrides etc. The gaining of hydrogen requires delivering energy e.g. some kinds of clean energy such as water energy, wind energy or solar one $[10,12,13,14]$.

Therefore the future belongs to hydrogen gained from 
solar energy in two-stage process. According to the opinion of experts, the first stage consists in converting solar light into electric energy by means of an extended system of solar cells. The second step in which the energy is consumed, would make it possible to gain hydrogen from the electrolysis process which results in cleavage of water bond. However a very high temperature is needed to do it as direct decomposition of water into hydrogen and oxygen occurs in temperature of $273^{\circ} \mathrm{C}$. Hydrogen, due to its low molecular mass and high gross calorific value, has the greatest energy - mass ratio and its explosion force is 2,5 -fold greater than that of conventional hydrocarbon fuels $[4,7,16,17]$.

The greatest advantage of hydrogen is the lack of $\mathrm{CO}_{2}$ emission during its combustion. However, its susceptibility to leaking, inflammability and ignition of hydrogen mixture, high hydrogen flame temperature, difficulty in its storing and transporting constitute problems.

Hydrogen in application as the only fuel for internal combustion engines has still a very long way to commercialization. Co-burning systems (of fuel mixtures) which are used today for combustion of hydrocarbon - hydrogen mixtures, are much closer to this aim. As resulted from some tests $[4,7,8,12]$, the replacing of a part of hydrocarbon fuels by hydrogen itself makes it possible to exploit favourable features of both the fuels.

Current research is focused on the co-burning of such fuel mixtures, in spark ignition engines, as : petrol- hydrogen, LPG - hydrogen, methane - hydrogen, natural gas - hydrogen. Research projects are also conducted on improvement of efficiency of self ignition engines by hydrogen adding. Effects of hydrogen addition on operational effectiveness of gas turbines are also investigated, usefulness of hydrogen to driving municipal buses is tested, and an German - Russian project (in the frame of CRYOPLANE project ) on hydrogen application in air civil transport and cosmic industry is under way too. $[3,5,18,21]$.

There are many possible hydrogen applications. They are only limited by human ingenuity and car industry corporations which are still not ready to reveal patents bought by them and results of research work done by their laboratories. Fortunately, various hydrogen-fed devices (available today almost for „everybody”) have been developed and their implementation in practice has just started.

\section{Hydrogen as a fuel of the future}

Most EU countries have set very ambitious plans in the frame of annual programs for production and implementation of substitute fuels for engines. However a part of car producers do not advise to use such solutions because they may generate unfavourable effects to engines. In spite of that, usage share of the fuels in application to road transport has to rise systematically. In response to critical opinions concerning this kind of fuel, EU works on development of new solutions - Fig.1a $[12,13]$. a)

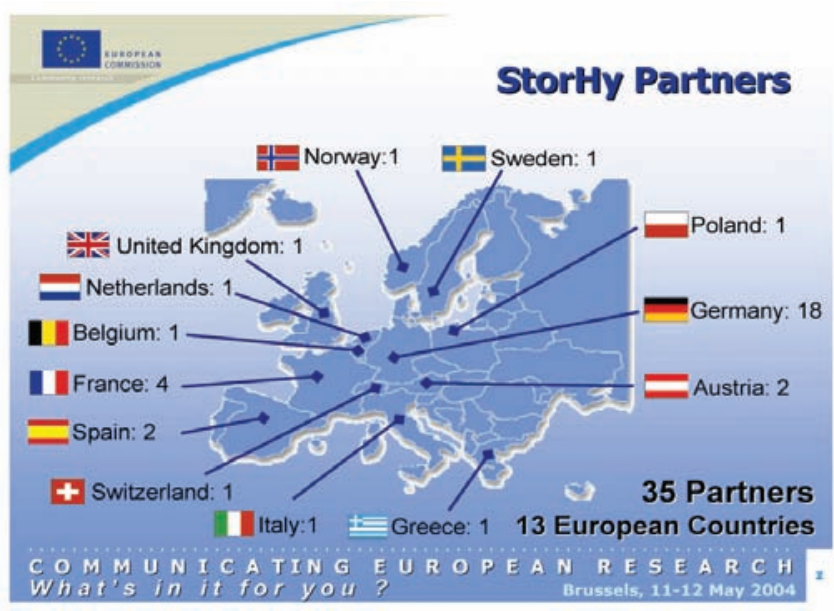

b)

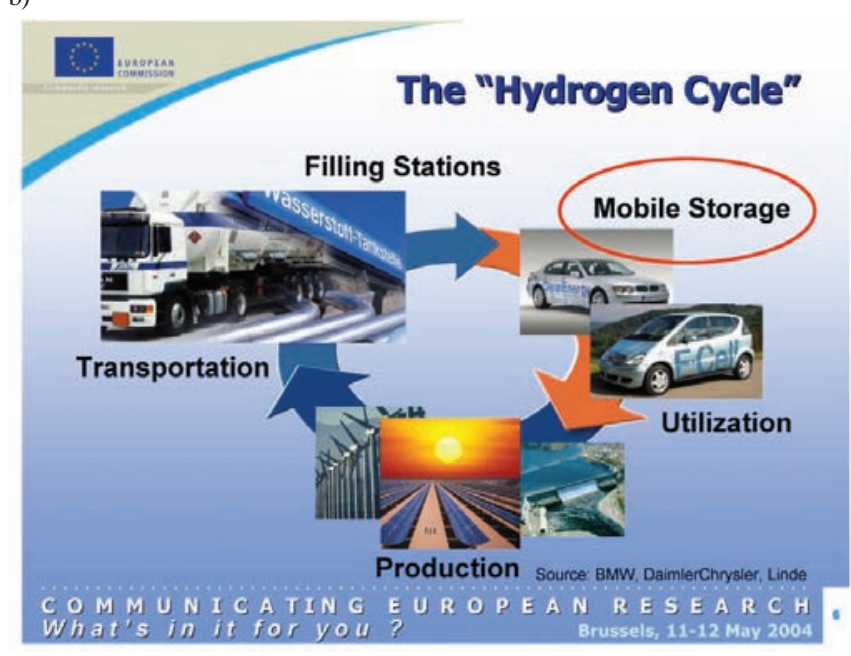

Fig.1. Participating countries (a) and hydrogen usage infrastructure (b) [13]

Program of development of alternative energy sources is a part of strategy of fighting against global warming -up. In 2012 in Poland this share reached about 5,79\%. (acc. Polish Office for Energy Regulation ) and has to increase step by step. In compliance with Polish Government's targets for the years of $2013 \div 2018$, in which minimum share of bio-components and other renewable fuels in total amount of fuels to be used per year is determined, in transport industry such share should reach : $7,10 \%$ in the years $2013 \div 2016,7,8 \%$ in 2017 , and $8,5 \%$ in 2018.

It is rather difficult to precisely conclude whether fuels of this kind have a negative impact on engines in view of a greater and greater level of complexity of such drives. Car producers should, already in engine design stage, take into account a mode of fuel supply, but they have once found themselves taken by surprise that to add some percent of a bio-fuel to conventional fuels or to use substitute fuels becomes obligatory $[4,7,11]$.

List of European countries participating in the EU Framework Program „StorHy”-6 dealing with a wide scope of issues on usage of hydrogen considered a future fuel for 
world-wide motorization, is presented in Fig. $1 \mathrm{~b}$.

The crucial target for the nearest years has to be the finding of many technical solutions as well as the breaking of nontechnical barriers to make this way further development of this field possible.The obstacles which are presently considered most important are : cost and durability of fuel cells, methods of production, storage and distribution of hydrogen fuel. A rather significant number of car industry concerns have been conducted for many years their own tests and research work on technologies using hydrogen as a main fuel - Fig. 2. $[8,10,11,14]$.

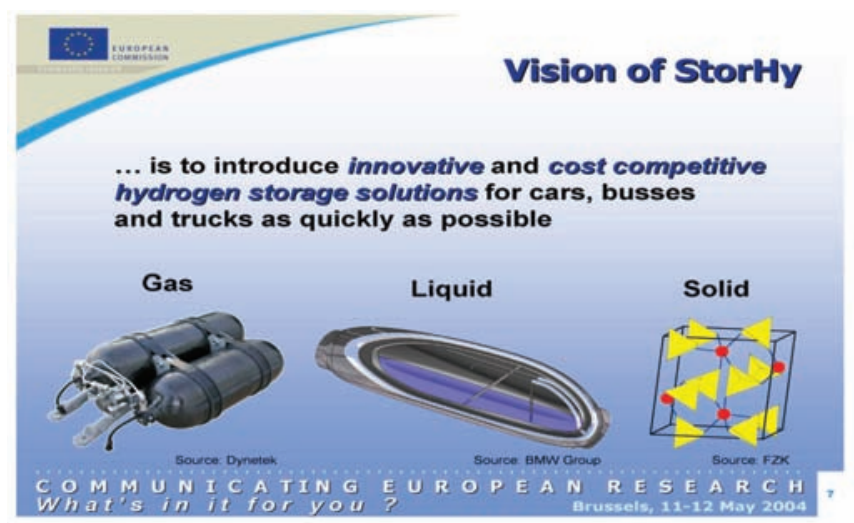

Fig.2. Schematic vision of „StorHy” program on implementation of innovative solutions for hydrogen storing in gasous, liquid and solid state for road transport purposes [13]

On the Earth, hydrogen in free state can be found mainly in the upper atmosphere layer where hydrogen and helium constitutes basic components of the atmosphere. However access to the resources is very difficult and the only solution for the winning -over of hydrogen in molecular form is to produce it. In an industrial scale, hydrogen is obtained from crude oil, natural gas and coal mainly by using steamreforming process through partial oxidation of heavy hydrocarbons or gasification of coal.

These methods are most efficient and also most profitable because their productivity reaches even $85 \%$. However a substrate for the reactions are raw materials whose exploitation should be limited. An additional detrimental issue is production of large amounts of carbon dioxide which contributes in growing greenhouse effect. The using of renewable sources for hydrogen production would have the least harmful effect on the environment [12].

One of the emission-free method of hydrogen production is electrolysis of water, which requires however a large amount of electric energy (Fig. 3).

The lowest voltage ( called the reversible voltage $\mathrm{E}$ ) at which water electrolysis can be conducted at room temperature, amounts to $1,23 \mathrm{~V}$. The electrolytic process occurs practically at voltage of $1,75 \div 2,3 \mathrm{~V}$ as a result of occurrence of voltage loss in electrolyzer, associated with activation of electrode processes and internal resistance of the cell. Theoretical consumption of energy for production of $1 \mathrm{~m}^{3}$ of hydrogen amounts to $2,96 \mathrm{kWh}$. Practical energy demand (Fig. 4) reaches $4,3 \div 5,7 \mathrm{kWh}$ per $1 \mathrm{~m}^{3}$ of hydrogen at applied voltage of $1,75 \div 2,3 \mathrm{~V}$.

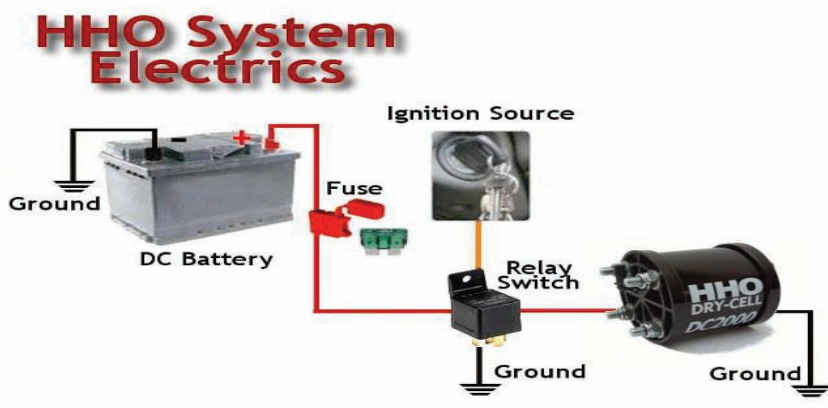

Fig.3. Schematic diagram showing how HHO system is included into electric network of a car

Progress in technology of electrolytic production of hydrogen and improvement of energy efficiency of the process may be reached by developing more effective electrodes and membranes, elevating the temperature and lowering the pressure necessary for conducting the electrolytic process as well as increasing density of current (in $1000^{\circ} \mathrm{C}$ temperature electric energy consumption drops to $2,83 \mathrm{kWh}$ per $1 \mathrm{~m}^{3}$ of hydrogen). Development of hydrogen production to a greater scale by applying electrolytic method is not possible at present because of its high costs, as electric energy consumption equals now about $4,5 \mathrm{kWh}$ per $1 \mathrm{~m}^{3}$ of hydrogen. As a result, cost of "electrolytic" hydrogen is threefold higher in comparison with that of hydrogen produced with the use of natural gas conversion, and twofold higher than that produced by coal gasification method. The world-wide hydrogen production stations based on water electrolysis operate on cheap electric energy delivered from water - power plants $[4,7,12]$.

It is a common opinion that in the future water electrolysis may be used at a greater extent for hydrogen production in the periods when demand for electric energy is low, as well as on the basis of nuclear energy and renewable energy sources, including solar energy. Recapitulation of particular hydrogen production methods is presented in Tab. 1.

A crucial factor which limits effective use of hydrogen as a fuel is its low density which results in that the main issue in implementing hydrogen technologies are techniques of its storage and transport.

In present hydrogen is used in :

- motorization ( for driving car engines );

- $\quad$ heating of buildings;

- water heating;

- kitchen cooker torches;

- robotics (e.g. as a source of driving prostheses).

It is still a long way to reach the instance when hydrogen fuels substitute the currently used mining fuels. It is however deemed that this direction in developing motorization is correct and united efforts of car producers could make this aim nearer. A breakthrough should be done to achieve the state in which hydrogen will be widely accessible and cheaper than other fuels. According to conservative data it may be assumed that about 2020 hydrogen fuel would be in use, but as a luxury product, and 20 years later it would be in common use. 
Tab. 1. Basic methods of hydrogen production

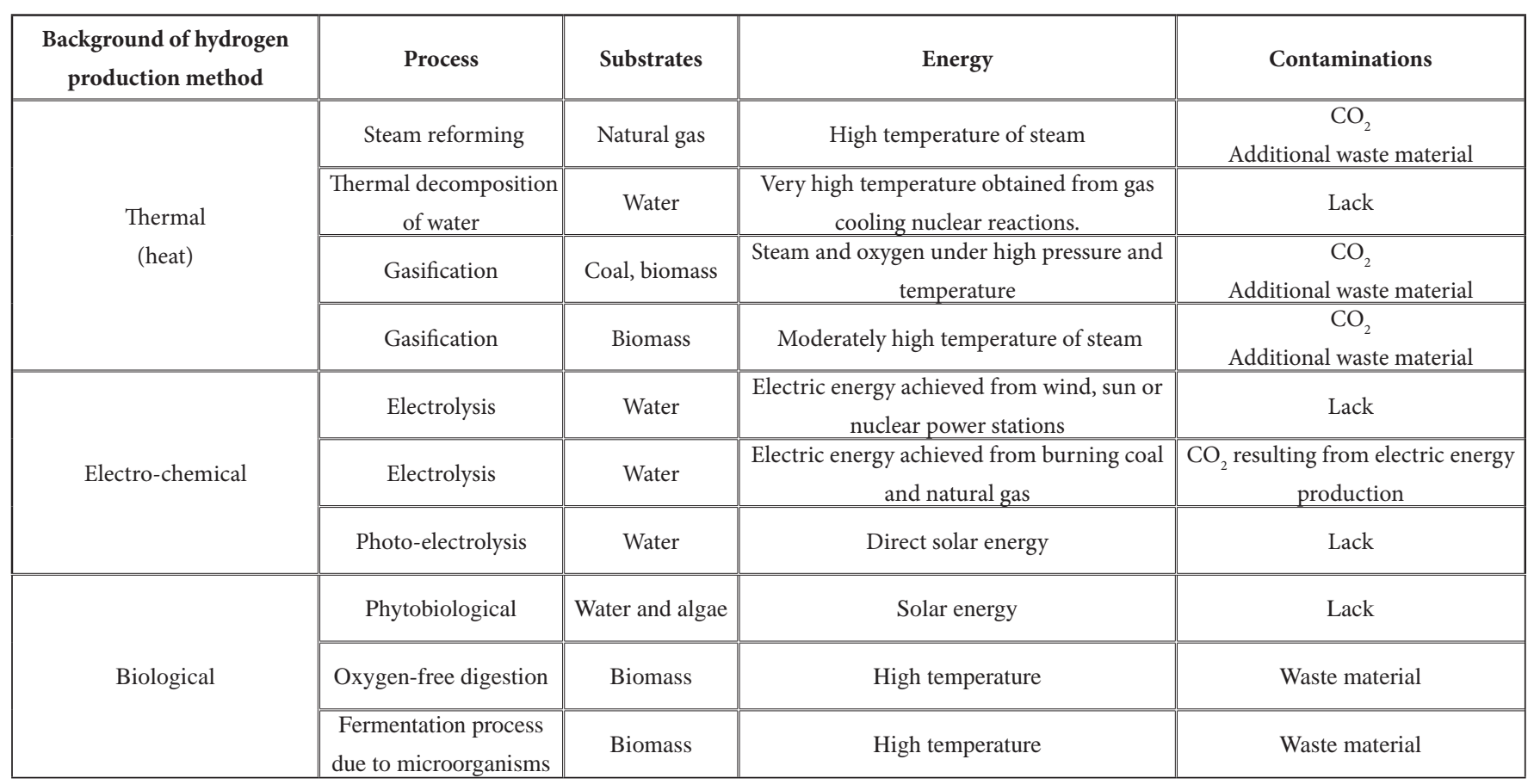

\section{Co-burning of hydrogen and hydrocarbon fuels}

\section{Co-burning of hydrogen in petrol engines}

Hydrogen has many features which are attractive for application in internal combustion, spark ignition engines. In this area, research is carried out in the aspect of using hydrogen either as the only fuel or an addition to conventional fuels such as petrol, natural gas, methane or LPG.

Because of its unique features hydrogen may be added to hydrocarbon fuels and thus improve some of their properties. Hydrogen is an excellent addition to petrol and gas; it may be burned at an extremely low concentration $(\varnothing=0,1)$, and while inserted in small amount to cylinder with a lean hydrocarbon mixture it extends range of combustibility of such mixtures (Fig. 4).

Hydrogen net ( mass) calorific value amounts to 119,8 $\mathrm{MJ} / \mathrm{kg}$ and is almost threefold greater than that of gas and petrol. However it should be remembered that fuel mixtures are measured in units of volume, i.e. by taking into account differences in density of hydrogen $\left(0,0824 \mathrm{~kg} / \mathrm{m}^{3}\right)$ and hydrocarbon fuels. It can be observed that net volumetric calorific value of hydrogen is $10,2 \mathrm{MJ} / \mathrm{m}^{3}$, and that of gas and petrol $-33,9 \mathrm{MJ} / \mathrm{m}^{3}$ and $216,4 \mathrm{MJ} / \mathrm{kg}$, respectively. Even though the stoichiometric ratio of air and fuel is greater, hydrogen occupies greater volume in relation to air than methane or petrol. It results from low calorific value of airhydrogen mixture because it contains a little lower amount of energy $\left(2913 \mathrm{~kJ} / \mathrm{m}^{3}\right)$ than stoichiometric mixture of methane and air $\left(3088 \mathrm{~kJ} / \mathrm{m}^{3}\right)$ and that of petrol and air $\left(3446 \mathrm{~kJ} / \mathrm{m}^{3}\right)$.
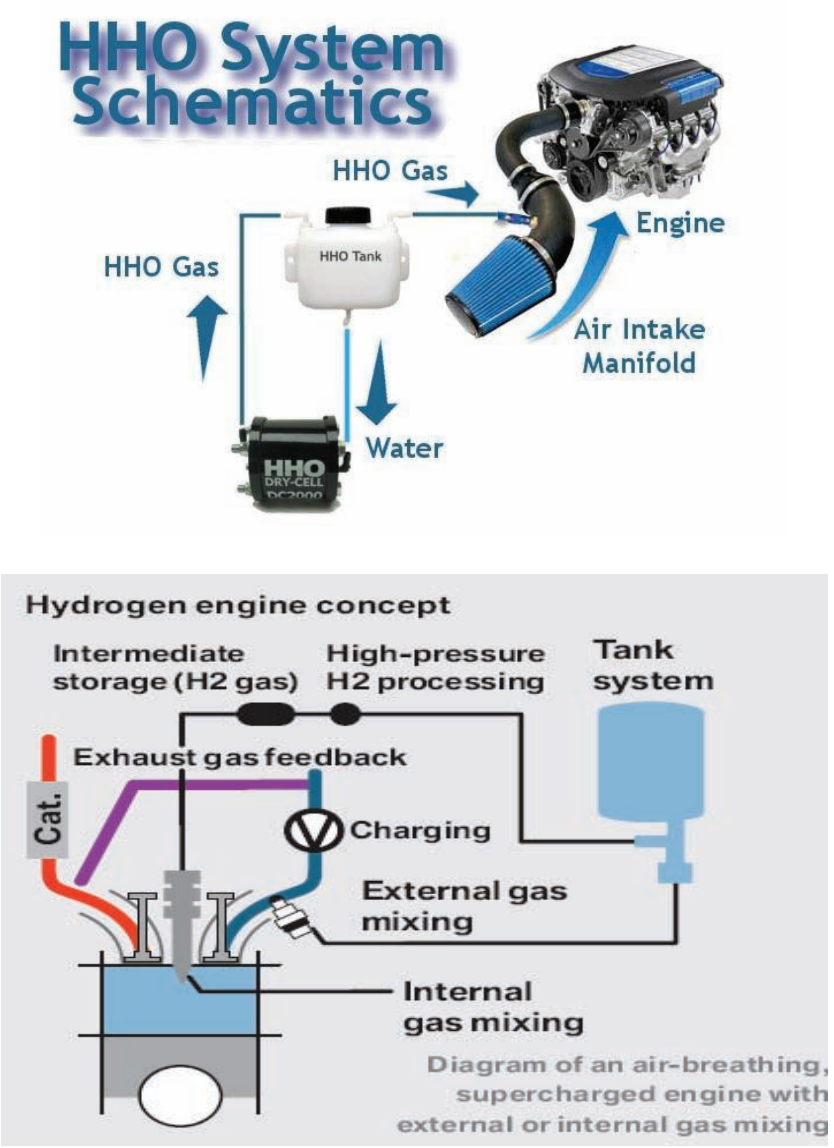

Fig. 4. A concept of the co-burning of produced hydrogen and hydrogenfed engine design 
Hydrogen combustion rate is seven times greater than that of methane and petrol, hence hydrogen combustion period is short. It means that less heat is transferred by flame in comparison with flame from burning hydrocarbon fuels. Only 17 to $25 \%$ of thermal energy released during combustion of hydrogen goes to environment by heat emission, but in case of methane this is $22-33 \%$, and petrol - $30-42 \%$.

In comparison with hydrocarbons hydrogen is characteristic of a high diffusivity which results in its good miscibility, turbulence and homogeneity of mixture. Very low value of its ignition energy facilitates immediate ignition and easy cold start-up.

Combustion temperature of hydrogen in air $\left(2045^{\circ} \mathrm{C}\right)$ is higher than that of methane $\left(1917^{\circ} \mathrm{C}\right)$, but lower than that of petrol $\left(2197^{\circ} \mathrm{C}\right)$. Damping gap through which flame develops is threefold smaller than the analogue parameter for hydrocarbons fuels, that means that flame will go closer to cylinder wall and combustion process will be more effective.

Tests on a single-cylinder engine showed that hydrogen addition to mixture of hydrocarbon fuels results in widening combustibility range of lean mixtures, and simultaneously lowers content of $\mathrm{CO}$ and $\mathrm{HC}$ in exhaust gas, but elevates $\mathrm{NO}_{\mathrm{x}}$ content. Because of a lower calorific value of hydrogen ( per one mol) in comparison with hydrocarbon fuels, thermal efficiency drops as a share of hydrogen in mixture increases.

Tests on serial engines showed that hydrogen addition results in lowering emission of $\mathrm{CO}$ and $\mathrm{HC}$ and increasing thermal efficiency while operating on lean mixture. In case of petrol, lowering emission of carbon- containing components was observed.

\section{Co-burning of hydrogen and natural gas (methane)}

Engines fed with natural gas LNG (Liquefied Natural Gas) or CNG (Compressed Natural Gas) are an alternative for petrol engines due to their favourable features among which the following are numbered :

- high calorific value,

- good ignition properties,

- high octane number, that enables to reach high compression ratio and large output,

- resistance to knocking combustion,

- low density, good diffusivity and homogeneity of mixture,

- broad range of ignition limits, that enables combustion of lean mixtures,

- natural gas can be co-burned with hydrogen.

An unfavourable feature of natural gas is its low energy density in comparison with petrol, which makes its compression or liquefaction necessary. Just in this state, i.e. in the form of LNG or CNG, natural gas is stored, transported and used. Interest paid to fuels of this kind is systematically growing, especially with a view of possibility of its co-burning with hydrogen.

\section{Co-burning of hydrogen and LPG or petrol}

The following conclusions were derived from the tests on the effect of hydrogen addition to liquefied gas (LPG) on emission of noxious components, thermal efficiency and performance of a single-cylinder engine $[3,7,11,14]$ :

- $\quad$ average effective pressure and thermal efficiency decreases as amount of added hydrogen increases; enriching LPG with hydrogen has no influence on rising thermal efficiency and average effective pressure;

- increasing amount of added hydrogen results in lowering amount of lost heat, accummulated heat and pressure;

- no difference in $\mathrm{CO}_{2}$ emission was found when an additional charge of hydrogen has been introduced, but a lower amount of oxygen was observed in the atmosphere of rich and lean stoichiometric mixtures because the additional hydrogen results in a higher emission of $\mathrm{CO}_{2}$;

- emission of hydrocarbons becomes lower when the relative air/fuel ratio is increased from 0,76 to 1,3 and hydrogen is added; emissions of $\mathrm{HC}$ are similar, as for their values, to those of $\mathrm{CO}$, when the air/fuel ratio increases from 0,76 to 1,3 ;

- emission of $\mathrm{NO}_{\mathrm{x}}$ becomes high when $10 \% \mathrm{~V} / \mathrm{V} \mathrm{H} 2$ is added at the value of $\lambda=0,9 \div 1,15$ ( as compared with pure LPG); maximum emission of $\mathrm{NO}_{\mathrm{x}}$ occurs at $\lambda=$ $=1,2$ ( relative air/fuel ratio); $20 \%$ addition of $\mathrm{H}_{2}$ results in about $20 \%$ rise of $\mathrm{NO}_{\mathrm{x}}$ emission (as compared with pure LPG).

\section{Hydrogen combustion in self- ignition engines}

The crucial target of the research which has been conducted so far on the co-burning of diesel oils and hydrogen in selfignition engines is to find conditions for better usage of energy of hydrocarbon fuels at a lower emission of noxious components and a lower smokiness of exhaust gas. First, air is compressed in cylinder up to the pressure of $1,4 \div 2,5 \mathrm{MPa}$. During compression air temperature rises up to $500 \div 600^{\circ} \mathrm{C}$, and close to its end a fuel charge is injected into cylinder. After a few miliseconds (ignition lag time) self ignition of fuel occurs. For successive split seconds, fuel is delivered to cylinder in which it evaporates and burns. During the combustion temperature of gas in cylinder may reach $1600 \div 2000^{\circ} \mathrm{C}$, and its pressure - $6 \div 10 \mathrm{MPa}$. Combustion process in diesel engine occurs at the fuel/air ratio equal to $0,70 \div 0,85$.

Thermal efficiency of diesel engines may reach $43 \%$, whereas efficiency of petrol engines is equal to about $25 \%$. Among diesel engines are remarkable the two-stroke lowspeed engines of output per cylinder up to $4300 \mathrm{~kW}$ whose thermal efficiency exceeds 50\%. Performance and thermal efficiency of diesel engines depend to a large extent on a kind and properties of used fuel. Ignition lag, combustion mode, power output, exhaust gas content and operational reliability of such engine depend on proper selection of fuel components 
and improvers.

Diesel oils $(\mathrm{ON})$ are mixtures of $\mathrm{C}_{11}-\mathrm{C}_{25}$ hydrogens which have boiling temperature in the range from 150 to $380^{\circ} \mathrm{C}$. Their hydrogen composition depends first of all on characteristics of a crude oil from which they were obtained and type of processes to which they were subjected. Commercial fuels introduced to market are desulfurizied but they still contain small amounts of sulfur as well as a WWA requiring more drastic combustion conditions.

Diesel engines may be fed, apart from diesel oils produced from crude oil, with vegetable oils or products of re-estrification of these oils. As results from the performed research, hydrogen addition amounting to $5-7 \% \mathrm{~m} / \mathrm{m}$ does not impose any large impact on effects of combustion of hydrocarbon fuels in self-ignition engines.

\section{Co-burning of hydrogen in gas turbines}

An increased attention to hydrogen is presently paid by electricity producers basing on gas turbines. Their use, in comparison with classical technologies, is simpler and more functional. Introduction of such facilities results from the fact that they are compact, light, fast starting-up, reliable and simple in operating. Low-power gas turbines are installed in industry, public institutions and places distant from aglomerations. They may operate in simple or combined cycles or co-geneneration mode and cost of their installation is low.

Two basic types of gas turbines may be distinguished:

- 1 st type - based on aircraft turbines modified for purposes of electric power generation; they may develop power up to $40 \mathrm{~kW}$ and produce electricity just in 3 min after starting,

- $\quad$ 2nd type - industrial gas turbines of output up to 300 MW, which require 10-40 min to start up.

A disadvantage of both the types of turbines is their emission level of $\mathrm{NO}_{\mathrm{x}}, \mathrm{CO}$ and $\mathrm{CO}_{2}$ as well; it depends on a kind of used fuel and its combustion conditions (temperature, pressure). For example, thermal synthesis of $\mathrm{NO}_{\mathrm{x}}$ starts in temperature of $1500^{\circ} \mathrm{C}$ and its content grows exponentially as temperature rises. In turbines with diffusive type of flame, both of stationary and jet engine type, flame temperature exceeds $2000^{\circ} \mathrm{C}$, which results in that exhaust gas contains a few hundred of $\mathrm{NO}_{\mathrm{x}} \mathrm{ppm}$.

Use of hydrogen as the only turbine fuel or co-burning it with a hydrocarbon fuel is able to reduce amount of emitted $\mathrm{HC}, \mathrm{CO}$ and $\mathrm{CO}_{2}$ components. Hydrogen is a promising fuel because of its high energy density $(120 \mathrm{MJ} / \mathrm{kg})$ which is twofold greater in comparison with conventional fuels. A drawback in using hydrogen for aircraft engines is its very low density $\left(0,082 \mathrm{~kg} / \mathrm{m}^{3}\right)$. Research on application of hydrogen as a fuel for gas turbines is recently still in the phase of preliminary tests $[11,14]$.

\section{Hydrogen generators}

A problem of contemporary industrial economy consists in that there is no firm link connecting running-low resources of fossil fuels with an alternative energy which exists but is still not available for various reasons. A fuel product obtained from electrolysis is hydrogen as well as oxygen produced ( under patent restrictions ) in a compact device called "Hydrogenic electrolyzer of fuels", where the produced hydrogen is subjected to co-burning process with a traditional fuel for engines.

Phenomenon of electrolysis is often used in engineering solutions called : hydrogen generator, hydrogen reactor, hydrogen producer. From the available descriptions of the generators facilitating water electrolysis and gas emission it results that they are built firmly, have jar-like struture (Fig.5) and are fitted with diode electricity supply, electrolyte control and charging devices.
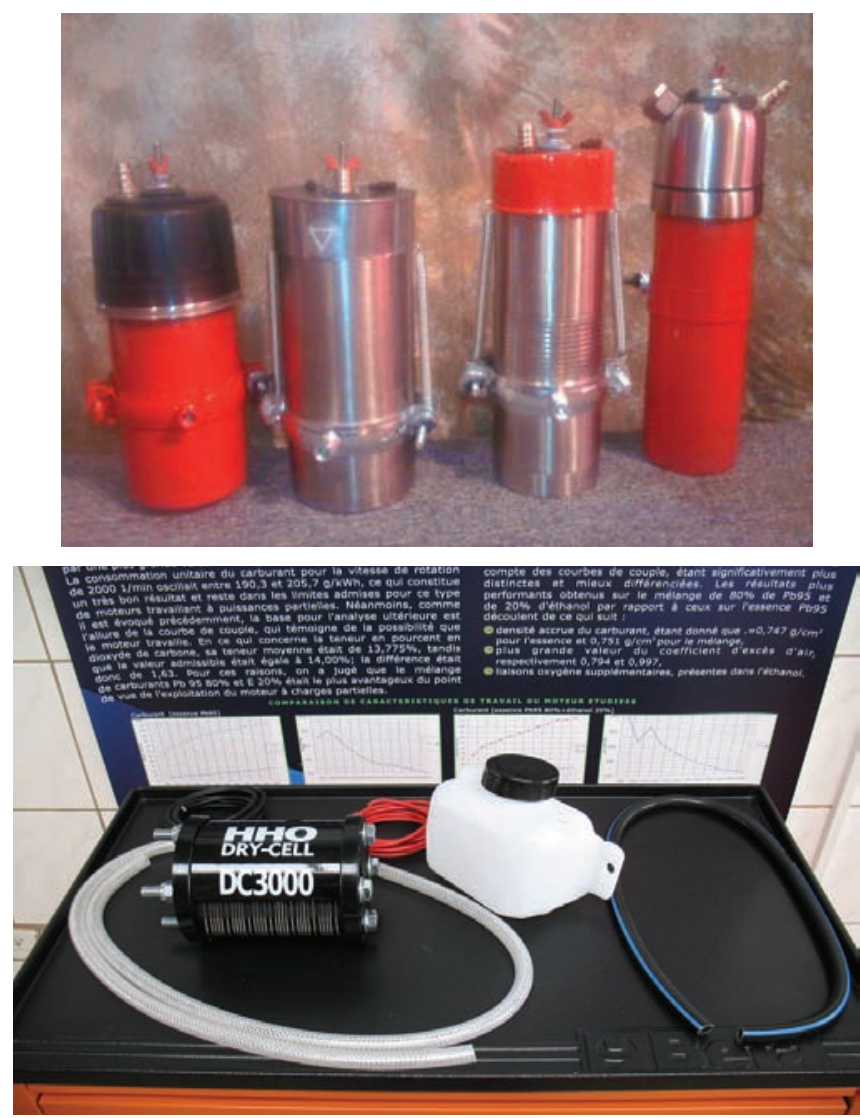

Fig. 5. Commercial version of older and today available hydrogen generators $(\mathrm{HHO})$

A HHO generator consisted of dry cells (Dry-cell DC3000) of total working surface area equal to about $1600 \mathrm{~cm}^{2}$ is a device similar to the above mentioned, patented one as to the elements used in core of water electrolysis chambers, as well as to the production process of contaminated hydrogen. Hydrogen in a volatile contaminated form is delivered directly to engine combustion chamber where it mixes with air and conventional fuel. Such solution is troublesome because of a dispersed necessary equipment (liquid tank, piping, circulation pump, electrolyte cooler, dryer, bubbler with net filter and throttling valve).

As a result, a compact hydrogen generator is obtained of a maximum capacity from the point of view of possible energy 
supply from an average car alternator - Fig.6.

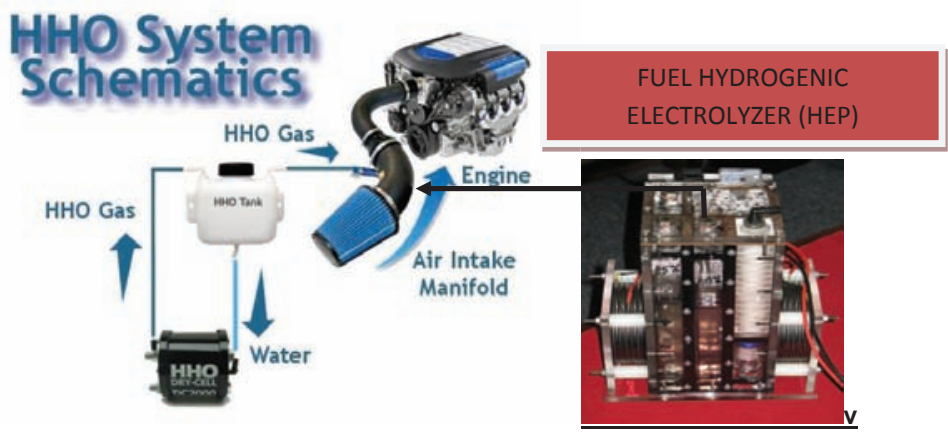

Fig. 6. Modular structure and simplicity of HEP device compared with the other solution - $\mathrm{HHO}$

The presented solution has been patented ( Patent application No. P.405757 on 24.10.2013 under Polish name: „Hydrogeniczny elektrolizer paliwowy (HEP)"). Its purpose is effective production of hydrogen and oxygen of a high purity while fed with direct current voltage of $12 \mathrm{~V}$ or $24 \mathrm{~V}$. The achieved mixture of hydrogen and oxygen is an additional, very useful component in producing stoichiometric mixture used for co-burning in combustion engines.

The main task requested from the invention is to reduce consumption of fossil crude oil fuels by about $25-40 \%$ without any need of introducing changes in construction of engines, to improve combustion efficiency of engine with special attention paid to fulfilling criteria of its durability and reliability. The object developed on the basis of the invention is a portable, compact, modular device of internal action in a closed cycle, intended for the application in car industry as a fuel electrolyzer.

The device is fed from a DC electricity source of $12 \mathrm{~V}$ or $24 \mathrm{~V}$ voltage and $25 \mathrm{~A}$ current. Demand for electric energy has been assumed on such safe level as not to exceed amount of losses resulting from vehicle operation, and which is optimized with regard to $60 \%$ loading effectiveness of reactor plates and the assumed service life of 10 years or $200000 \mathrm{~km}$ mileage. Hydrogen and oxygen is achieved from the invented device as a result of the transformation ( water electrolysis ). In the process of electrolysis twice more hydrogen than oxygen is obtained. Oxygen is crucial for combustion of air-fuel mixture from the point of view of improving flame stabilization which consequently improves combustion process, especially during idle running where content of oxygen is limited and which leads to increasing fuel consumption.

The invented device „HEP”, due to a novel solution of its casing and application of modern materials, is a safe and unattended facility except of necessity of periodical complementing it with electrolytic fluid and destillated water. The device is of a simple structure and easy for maintenance, very effective; it does not generate any gas pressure (hence no loss of tightness is possible), as well as it has not any flow transmitting pipes whose damage or a leakage from it is undesirable because of a high oxidation suceptibility of aluminium. Fuel winning in the form of hydrogen and oxygen flows through channels inside walls of reactor casing. Gas injection consists in its vacuous suction - off from car air intake, which transports gas directly to combustion chamber mixing it with air and fuel, after its prior purification, dehydration and drying. Injection point is located behind the air filter area and behind MAF sensor which measures air flow from intake collector to combustion chamber of engine.

In the proposed solution was applied a cell working control which ensures the following:

- control over work of $\lambda$ - sonde by using EFIE controller (i.e. control of oxygen amount in mixture as the controller modulates signal sent from $\lambda$-sonde and transmits to computer its modulated value as to oxygen amount in exhaust gas, lowering this way a fuel dose inserted to combustion chamber); EFIE controller interacts with $\lambda$-sondes operating under voltage ranging from 0 to $1 \mathrm{~V}$;

- control of amount of fuel dose ( hydrogen + oxygen ) delivered to combustion chamber (precise regulation of current strength by using a signal from MAP or MAF sensor in a car);

- control of current strength by using PWM;

- control of a ignition switch relay (40A) which switches on and off the cell when car engine starts-up and stops, with the use of alternator excitation current.

The proposed „HEP” solution uses electric energy available from car alternator. It has a compact, modular casing of a high chemical and mechanical resistance, in which three reactor cells are accommodated.

The invented device „HEP”, a fuel electrolyzer generating chemical energy (in volatile state) produced from a safe portion of car electric energy losses, is an innovative fuelling solution for contemporary car driving units. In consequence, its use leads to lowering consumption of fossil fuels and $\mathrm{CO}_{2}$ emission to atmosphere. The object was so designed and manufactured as not to require any maintenance in service, except of supplementing electrolytic fluid by amount of 50 $\mathrm{ml} \mathrm{KOH}$ and 11 of destilled water per $1000 \mathrm{~km}$ travelled by a car of $1600 \mathrm{~cm}^{3} \div 2200 \mathrm{~cm}^{3}$ cubic capacity of engine, periodically surveyed to keep it serviceable.

Finally, a significant rise in engine combustion effectiveness was reached with taking into account production cost of the invented device and its practically non-invasive implementation, resulting in 25\% conventional fuel savings ( with a future target of $40 \%$ ). Fig.7 shows a schematic top view of the device and an overall photograph of fuel cell.

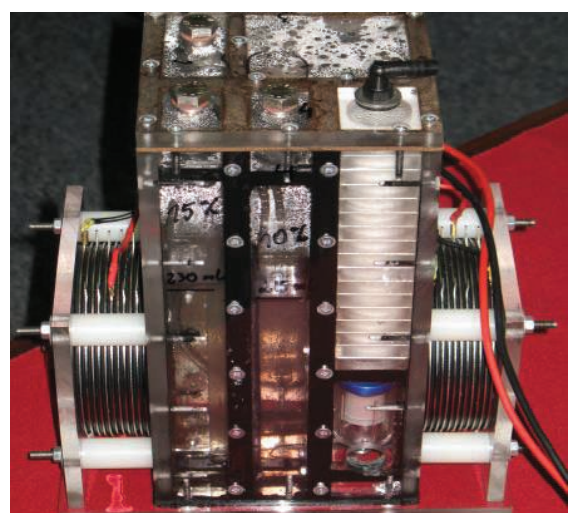




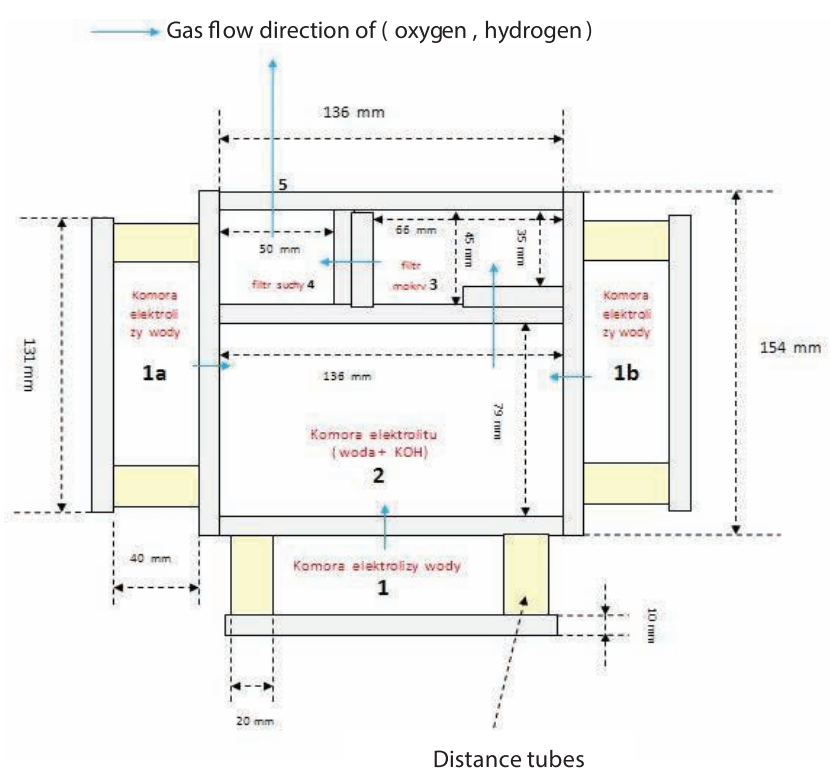

Fig.7. Top view of a fuel cell and its photograph. 1, 1a, 1b - Water electrolysis chamber, 2 - Electrolyte chamber ( water + $\mathrm{KOH}$ ), 3 - Wet filter, 4 - Dry filter.

The first manufactured pieces of the innovative cell were subjected to laboratory tests on stationary test beds for engines as well as operational tests on two passenger cars ( Fig. 8). The assumed test program on economic effectiveness of the cell and reliability of engines is time-consuming and long-lasting.
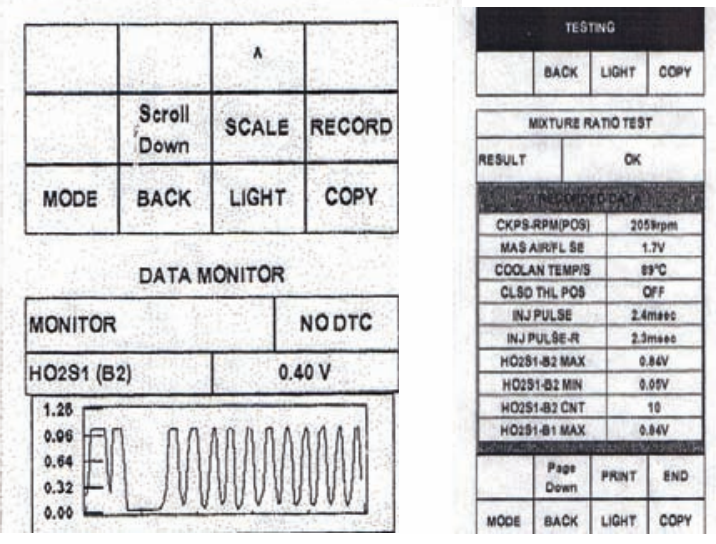

Fig. 8. Measurement of $\lambda$ - sonde parameters and fuel mixture content in nominal conditions for spark-ignition engine in a stable, idle running state [14]

\section{Preliminary tests - their methods and results}

1. The tests were performed to recognize effects of application of 70A current, delivered from external consumers, to a Xara Citroen engine of 1,9 l cubic capacity on consumption of fuel mixture consisted of petrol and an additional dose of hydrogen.

2. The tests were carried out on a stationary test stand in UTP laboratory with the use of a KTS 520 diagnostic instrument.

3. The tests were conducted at idle running speed of the engine.

4. The hydrogen generator was fed with 50 A current from an external source (not from the car itself) at hydrogen output of about $5 \mathrm{dm}^{3} / \mathrm{min}$.

5. Prior to the tests it was proved that the applied independent control over $\lambda$ - sonde performance did not influence at all fuel consumption within the whole working range, consequently the additional EFIE controller was switched -off.

6. Each measurement was executed for two critical voltage applied to $\lambda$-sonde ( about 55 and $650 \mathrm{mV}$ ).

7. Use was made of "Time runs" option which covers four most significant parameters: engine rotational speed, times of injection to cylinders $1 / 4$, times of injection to cylinders $2 / 3$, voltage of $\lambda$ - sonde.

8. An exemplary window showing the test results in the form of time-runs is attached below and the remaining test results are given in the form of the tables taken from subsequent windows.

\section{Exemplary results of the tests [14]}

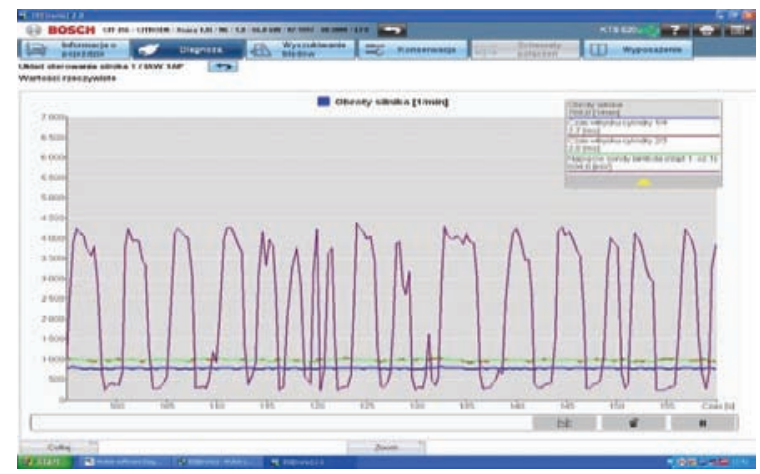

Fig. 9. Exemplary window of the test results

1. Without any electric current load from onboard devices, for $\lambda_{\text {max }}$ :

Petrol

\begin{tabular}{|c|c|}
\hline $\begin{array}{l}\text { Obroty silnika } \\
768,0[1 / \mathrm{min}] \\
\end{array}$ & Engine rotational speed \\
\hline $\begin{array}{l}\text { Czas wtrysku cylindry } 1 / 4 \\
2.7 \text { [ms] }\end{array}$ & Time of injection cyl. 1, 4 \\
\hline $\begin{array}{l}\text { Czas wtrysku cylindry } 2 / 3 \\
2,8 \text { [ms] }\end{array}$ & Time of injection cyl. 2,3 \\
\hline $\begin{array}{l}\text { Napięcie sondy lambda (rząd } 1 \\
604,0[\mathrm{mV}]\end{array}$ & $\begin{array}{l}(-c z .1) \\
\text { Voltage of } \lambda \text { - sonde }\end{array}$ \\
\hline
\end{tabular}

Petrol + hydrogen

\begin{tabular}{l|l|}
\hline Obroty silnika & \\
$800,0[1 / \mathrm{min}] \quad 453,0 / 800,0$ \\
\hline Czas wtrysku cylindry $1 / 4$ & \\
2,7 [ms] & \\
\hline Czas wtrysku cylindry $2 / 3$ & \\
2.7 [ms] & \\
\hline Napiecie sondy lambda (rzad 1 & $\mathrm{cz.1})$ \\
$631,0[\mathrm{mV}]$ & \\
\hline
\end{tabular}

2. Without any electric current load from onboard 
Petrol

devices, for $\lambda_{\min }$ :

\begin{tabular}{l}
\hline Obroty silnika \\
768,0 [1/min] \\
Czas wtrysku cylindry $1 / 4$ \\
2,8 [ms] \\
Czas wtrysku cylindry $2 / 3$ \\
2,8 [ms] \\
Napięcie sondy lambda (rzad $1-\mathrm{Cz} .1)$ \\
59,0 [mV] \\
\hline
\end{tabular}

Petrol + hydrogen

\begin{tabular}{|c|c|}
\hline $\begin{array}{l}\text { Obroty silnika } \\
800,0[1 / \mathrm{min}]\end{array}$ & \\
\hline $\begin{array}{l}\text { Czas wtrysku cylindry } 1 / 4 \\
2,8 \text { [ms] }\end{array}$ & \\
\hline $\begin{array}{l}\text { Czas wtrysku cylindry } 2 / 3 \\
2,8 \text { [ms] }\end{array}$ & \\
\hline $\begin{array}{l}\text { Napiecie sondy lambda (rzad } 1 \text { - } \\
55,0[\mathrm{mV}]\end{array}$ & cz. 1) \\
\hline
\end{tabular}

3. 70 A current load from onboard devices, for $\lambda_{\text {min }}$ : Petrol

\begin{tabular}{|c|c|}
\hline $\begin{array}{l}\text { Obroty silnika } \\
832.0[1 / \mathrm{min}]\end{array} \quad 212.7 / 832.0$ & \\
\hline $\begin{array}{l}\text { Czas wtrysku cylindry } 1 / 4 \\
4.6 \text { [ms] }\end{array}$ & \\
\hline $\begin{array}{l}\text { Czas wtrysku cylindry } 2 / 3 \\
4.6 \text { [ms] }\end{array}$ & \\
\hline $\begin{array}{l}\text { Napiecie sondy lambda (rzad 1 } \\
63.0[\mathrm{~m} v]\end{array}$ & $-c z .1)$ \\
\hline
\end{tabular}

Petrol + hydrogen

\section{obroty silnike}

$864.0[1 / \mathrm{m} 655.3 / 864,0$

Czas wtrysku cylindry 1/4

4,2 [ms]

Czas wtrysku cylindry $2 / 3$

4,2 [ms]

Napiecie sondy lambda (zad $1-c z .1)$

$67.0[\mathrm{mV}]$

4. 70 A current load from onboard devices, for $\lambda_{\max }$ :

Petrol

\begin{tabular}{|c|c|}
\hline $\begin{array}{l}\text { Obroty silnika } \\
864,0[1 / \text { mir } 330,7 / 864,0\end{array}$ & \\
\hline $\begin{array}{l}\text { Czas wtrysku cylindry } 1 / 4 \\
4.6 \text { [ms] }\end{array}$ & \\
\hline $\begin{array}{l}\text { Czas wtrysku cylindry } 2 / 3 \\
4,7 \text { [ms] }\end{array}$ & \\
\hline $\begin{array}{l}\text { Napiecie sondy lambda (r } \\
671,0[\mathrm{~m} / \mathrm{l}\end{array}$ & ad $1-c z .1)$ \\
\hline
\end{tabular}

Petrol + hydrogen

\begin{tabular}{|c|c|}
\hline $\begin{array}{l}\text { Obroty silnika } \\
864,0 \text { [1/min] } \quad 712.4 / 864,0\end{array}$ & \\
\hline $\begin{array}{l}\text { Czas wtrysku cylindry } 1 / 4 \\
3,9 \text { [ms] }\end{array}$ & \\
\hline $\begin{array}{l}\text { Czas wtrysku cylindry } 2 / 3 \\
3.9 \text { [ms] }\end{array}$ & \\
\hline $\begin{array}{l}\text { Napiecie sondy lambda (rzad } \\
631,0[\mathrm{mV}]\end{array}$ & $-C Z .1)$ \\
\hline
\end{tabular}

Tests of fuel consumption and mixture content for 1,9 1 petrol engine when a hydrogen generator fed with electric current from car, is used.

1. Measurement of consumption (injection time) of fuel without hydrogen, for $\lambda_{\max }$ and $\lambda_{\text {min }}$

\begin{tabular}{|c|c|}
\hline $\begin{array}{l}\text { Obroty silnik } \\
800,0[1 / \mathrm{min}\end{array}$ & $299.2 / 800.0$ \\
\hline $\begin{array}{l}\text { Ciśnienie w } \\
336.0 \text { [mbar }\end{array}$ & urze dolat. \\
\hline $\begin{array}{l}\text { Czas wtrysk } \\
3.2 \text { [ms] }\end{array}$ & 1 cylindry $1 / 4$ \\
\hline $\begin{array}{l}\text { Napiecie so } \\
31.0[\mathrm{mV}]\end{array}$ & fidy lambida (rzad 1 -cz. 1) \\
\hline
\end{tabular}

\begin{tabular}{l} 
Obroty silnika \\
800,0 [1/min] \\
Cisnienie w rurze dolot. \\
328.0 [mbar] \\
Czas wtrysku cylindry 1/4 \\
3.1 [ms] \\
Napiecie sondy lambda (rzad $1-\mathrm{cz} .1)$ \\
\hline
\end{tabular}

Measurement of consumption (injection time) of fuel with hydrogen left part of the diagram - without EFIE control - right part - EFIE control operates

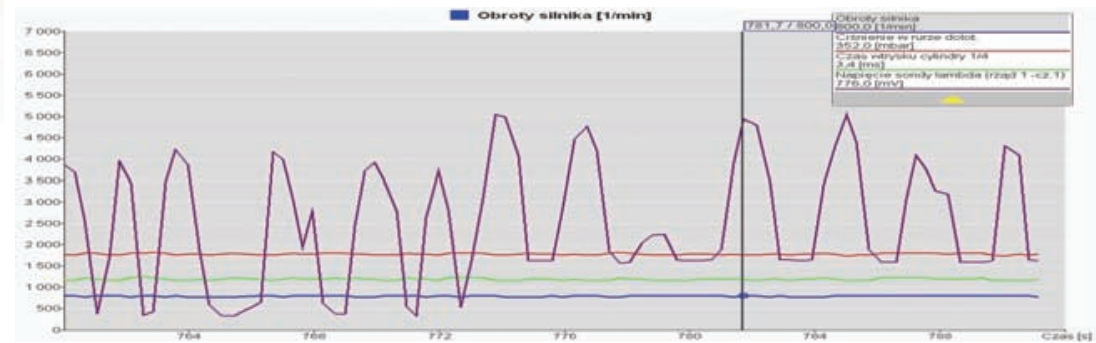

a) Table of results of the tests at hydrogen addition,

\begin{tabular}{l} 
Obroty silnika \\
800,0 [1/min] \\
Cisnienie w rurze dolot. \\
356,0 [mbar] \\
\hline Czas wtrysku cylindry 1/4 \\
3.4 [ms] \\
Napiecie sondy lambda (rzad $1-\mathrm{cz} .1)$ \\
631,0 [mV]
\end{tabular}


without EFIE control, for $\lambda_{\text {max }}$ and $\lambda_{\text {min }}$

Obroty silnika
800.0 [1/min]
Cisnienie w rurze dalot.
368.0 [mbar]
Czas wtrysku cylindry $1 / 4$
3.7 [ms]
Napiecie sondy lambda (rzad $1-\mathrm{cz} 1)$
55.0 [mV]

b) Table of results of the tests at hydrogen addition, with EFIE control, for $\lambda_{\text {max }}$ and $\lambda_{\text {min }}$

\begin{tabular}{l} 
Obroty silnika \\
1000.0 [1/min] \\
\hline Ciśnienie $\mathrm{w}$ rurze dolot. \\
352.0 [mbar] \\
Czas wtrysku cylindry 1/4 \\
3.4 [ms] \\
Napiecie sondy lambda (rzad $1-\mathrm{cz} .1)$ \\
776.0 [mV]
\end{tabular}

\begin{tabular}{|c|c|}
\hline $\begin{array}{l}\text { Obraty silr } \\
800.0[1 / \mathrm{n}]\end{array}$ & $786.6 / 800.0$ \\
\hline $\begin{array}{l}\text { Ciśnienie } \\
360.0[\mathrm{mb}\end{array}$ & $\begin{array}{l}\text { Wrurze dolot. } \\
\text { ar] }\end{array}$ \\
\hline $\begin{array}{l}\text { Czas wtry } \\
3.5[\mathrm{~ms}]\end{array}$ & sku cylindry $1 / 4$ \\
\hline $\begin{array}{l}\text { Napiecie } \\
251.0[\mathrm{~m} \\
\end{array}$ & $\begin{array}{l}\text { Sondy lambda (rzad } 1-c z .1 \text { ) } \\
\text { ] }\end{array}$ \\
\hline
\end{tabular}

2. Analysis of exhaust gas : without hydrogen addition to fuel ( left ), with hydrogen addition and without EFIE control for 10A current from car alternator (in the middle), and with hydrogen addition and without EFIE control for 21A current from car alternator (right) [14].
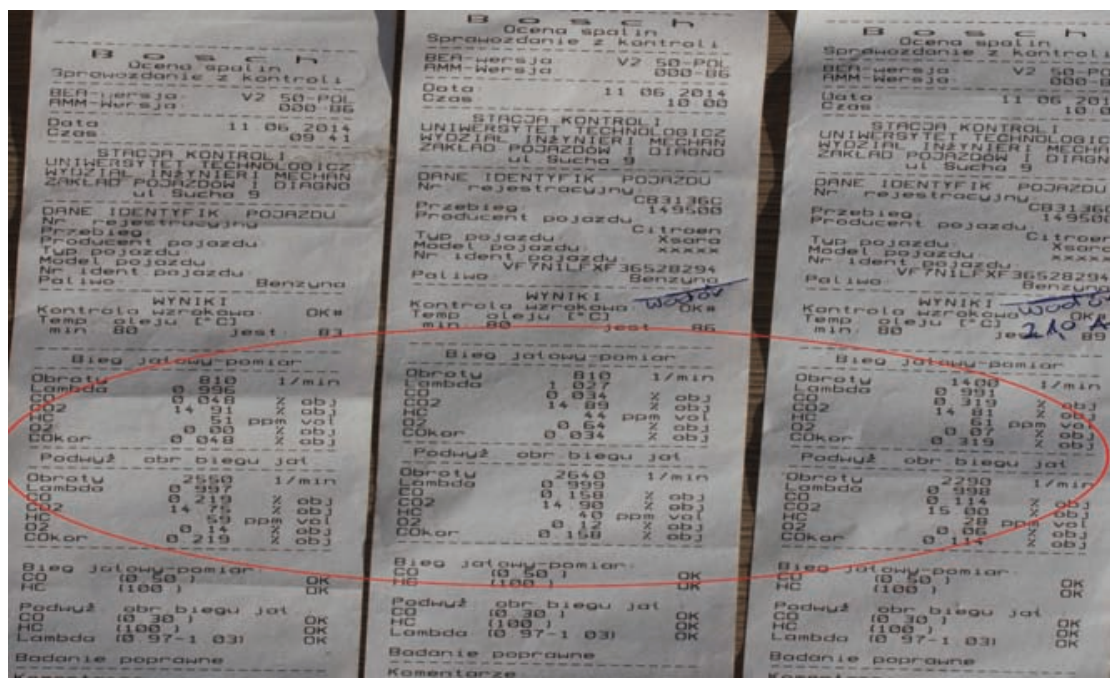

\section{Recapitulation}

The future demands of car producers concerning nul emission of exhaust gas toxic components as well as EU regulations on obligatory use of alternative fiels from renewable sources create prospects for implementation of hydrogen fed cars in a not distant time. A way to hydrogen use is not straight because it requires not only to develop an appropriate technical background for feeding systems of conventional engines but also an appropriate infrastructure which must consume very big material resources.

Hydrogen is a fuel of a high energy content per unit of mass ( threefold greater than that of petrol). Despite technical difficulties connected with its implementation, hydrogen may become a future fuel as its use does not disturb natural environment balance and hydrogen resources are practically unlimited.

Among the most important merits of hydrogen the following may be numbered : wide range of its combustibility, low ignition energy, high diffusivity factor, high combustion rate, high ignition temperature. Exhaust gas content is the basic aspect which differs hydrogen from other fuels. Because of lack of carbon in the fuel, carbon dioxide practically is absent in engine exhaust gas that makes it the most ecologically clean fuel. Water vapour, being the product of hydrogen combustion, is the main component of exhaust gas. And, only some amounts of nitrogen oxides and traces of $\mathrm{CO}$ and $\mathrm{HC}$, resulting from combustion of diesel oils, can be found in exhaust gas.

There are a few solutions for hydrogen use as a fuel for combustion engines. The most prospectous is its implementation in co-burning process, that was implemented in the solution presented in this paper.

More and more advanced car driving units demand to apply higher and higher criteria for engine efficiency and reliability, and, in consequence, to highlight how to adjust $\mathrm{HHO}$ system to engines with carbouratter feeding system and how to do it in a vehicle fitted with an engine with multi point injection and variable timing phase.

Potential hydrogen applications are very wide and the searching for alternative energy sources is a must, that has been shortly discussed in this paper. It is worth to continue the research on possible winning and using new energy sources, which often leads to innovative theoretical and prototype solutions and - finally - their industrial applications.

\section{Bibliography}

1. Delucchi A., Micheals P., McArdle P., Singh M., Marland G., Lindzen R., Edgerton S.: Alternatives to Traditional Transportation Fuels. Greenhouse Gas Emissions; Vol.2, 1996. 
2. Doppler M.: Development of and prospects for hybride hydrogen drive for cars ( in Polish). Akademia GórniczoHutnicza im. Stanisława Staszica, Kraków (Staszic Mining and Metallurgy Academy of Cracow), 2005.

3. Dzida M., Olszewski W.: Comparing combined gas tubrine/steam turbine and marine low speed piston engine/steam turbine systems in naval applications. Polish Maritime Research, No.4(71), Vol.18, 2011.

4. Feldzensztajn A., Pacuła L., Pusz J.: Hydrogen - a fuel of the future (in Polish). IWT, INTECH, Gdańsk, 2003.

5. Gębura A.: Diagnosing turbine engine bearing structures with the aid of FAM-C and FDM-A methods. Polish Maritime Research, No. 1(59), Vol.16, 2009.

6. Girtler J., Korczewski Z., Mańczak J.: Operational problems of large power diesel engines combusting biofuels, considered together with assessment of their operation. Polish Maritime Research, No 2 (65), Vol. 17, 2010.

7. Holladay J. D., Hu J., King D. L., Wang Y.: An overview of hydrogen production technologies. Catalysis Today 2009, 139, (4), pp. 244-260.

8. Kaszowski P., Dzida M., Krzyślak P.: Calculations of labyrinth seals with and without diagnostic extraction in fluid-flow machines. Polish Maritime Research, No 4 (80), Vol. 20, 2013.

9. Korczewski Z.: Exhaust gas temperature measurements in diagnostic examination of naval gas turbine engines. Polish Maritime Research, No. 4(71), Vol.18, 2011.

10. Kothari R., Buddhi D., Sawhney R. L.: Comparison of environmental and economic aspects of various hydrogen production methods. Renewable and Sustainable Energy Reviews, 2008, 12, (2), pp.553-563.

11. Little A.D.: Guidance for Transport Technologies: Fuel Choice for Fuel Cell Vehicles, 2002.

12. Madejska B.: Legal aspects of low-emission shipping in the light of provisions of "sulphur directive" adopted by the European Union. Polish Maritime Research, No 4 (80), Vol. 20, 2013.

13. Raport: Clean power for transport - Frequently asked questions. European Commission, Brussels, January, http://europa.eu/rapid/press-release_IP-13-40_en.htm, (2005) 2013.

14. Raport z badañ (Deczyñski, Minder), badania rozpoznawcze, UTP, Bydgoszcz, 2014.

15. Rudnicki J.: The evaluation of the vibration measurement usability of electronic indicator LEMAG „PREMET C”. Journal of Polish CIMAC, Vol. 7 No. 2, Gdańsk, 2012.

16. Surygała J.: Hydrogen as a fuel (in Polish). Wydawnictwo Naukowo-Techniczne (Scientific Technical Publishers): Warszawa, 2008.

17. Żółtowski B., Niziński S.: Modelling the processes of exploitation machines. ISBN - 83-916198-3-4, Bydgoszcz-Sulejówek, 2002 pp. 250.

18. Żółtowski B., Cempel C.: Engineering of diagnostics machines. PTDT, ITE - PIB, Radom, ISBN 83-7204-4147, 2004 s.1109.

19. Żółtowski M.: Informatic systems in production engineering management (in Polish). ITE - PIB, Radom ISBN 978-83-7204-919-3, 2011, s.271.

20. Żołtowski M.: Investigations of harbour brick structures by using operational modal analysis. Polish Maritime Research, No 1 (81), Vol. 21, 2014.

21. http://www.eere.energy.gov/hydrogenandfuelcells/ hydrogen/production.html

22. http://www.euweb.de/fuel-cell-bus/storage.htm

CONTACT WITH THE AUTORS

Bogdan Żółtowski,
Mariusz Źółtowski
bogzol@utp.edu.pl, mazolto@utp.edu.pl

University of Technology and Life Sciences 11/12 Narutowicza St. 80 - 233 Gdańsk

Poland 